\title{
JUURNAL.RU
}

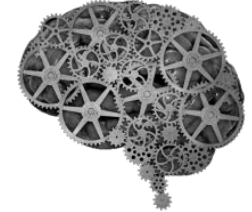

COMPANY GROUP "INTELLEKT"

Киреева Н.А. Саратовский сочиально-экономический институт Российского экономического университета имени Г.В.Плеханова Саратов, Россия

doi: 10.18411/lj2016-3-15

\section{Обоснованность введения единой валюты в рамках Евразийского Экономического Союза}

В современных условиях вопросы интеграции, в том числе в финансовой и валютной сферах, являются важнейшими для развития страны. Сначала появление американского доллара в качестве мировой валюты, затем конкурентоспособного (не без сложностей, впрочем) евро и ряда других валют предопределили становление мультивалютного финансового рынка. Когда ЕС ввел единую валюту, общую для ряда стран, понимание о финансовой интеграции качественно изменилось.

Одним из важнейших факторов экономического развития стран является их интеграция в мировое хозяйство. В современном мире экономические интеграционные процессы развертываются в области торговли, финансов и в валютной сфере. Россия также является участником современных интеграционных процессов, в т.ч. на евразийском пространстве.

Немного истории. Спустя ряд соглашений 90-х годов о поэтапном формировании Таможенного союза 10 октября 2000 г. в итоге был подписан Договор об учреждении Евразийского экономического сообщества. В его нормах-целях не нашли отражения положения о необходимости валютной интеграции. Впрочем, в заявлениях глав государств - членов сообщества уже 
тогда звучали идеи о постепенной валютной интеграции, вплоть до введения единой валюты ${ }^{1}$.

В 2007 г. был принят Договор «О создании единой таможенной территории и формировании таможенного союза", впоследствии ставший основой для формирования порядка 40 международных соглашений, предусматривающих механизмы действия Таможенного союза. Всё это не могло не сказаться на активизации полемики по поводу будущего - перспектив создания единой валюты в рамках ряда государств.

Споры эти намечались, впрочем, много ранее. Еще на встрече глав Центральных банков стран СНГ в феврале 2001 года активно говорили о введении единой валюты. После даже предлагали создать некий вариант европейского «евро» - валюту «евраз» в рамках $\mathrm{EAC}^{2}$.

Неудивительно, что после всего необходимость формирования если не единой валюты, то хотя бы предпосылок для «сотрудничества в валютной сфере», нашла отражение в ряде международных актов. В частности, одной из задач дальнейшей интеграции Декларация о евразийской экономической интеграции (от 18 ноября 2011 г.) поставила «углубление сотрудничества в валютной сфере».

Решением Высшего евразийского экономического совета были введены в действие с 1 января 2012 года 17 базовых международных договоров, формирующих Единое экономическое пространство.

В конечном счете, наивысшую степень интеграции на данном этапе декларирует Договор от 29 мая 2014 г. о Евразийской экономическом союзе, в котором, в статье 64 раздела 14, содержатся положения о необходимости повышения роли национальных валют государств-членов, разработки согласованной валютной политики на основе ряда принципов.

\footnotetext{
${ }^{1}$ Долгов С. И. Глобализация экономики: новое слово или новое явление? М., Прогресс, 2013, С. 62.

${ }^{2}$ См. об этом: Глазьев С. Ю., Бадалян Л. Г., Криворотов В. Ф. Евразийская резервная система и выход из финансового кризиса // Прогнозы и стратегии, 2014.
} 
Помимо общих, превентивных мер, направленных на повышение доверия к национальным валютам, в п. 1 ч. 1 ст. 64 указывается на необходимость «поэтапного осуществления гармонизации и сближения подходов к формированию и проведению валютной политики в том объеме, в каком это соответствует сложившимся макроэкономическим потребностям интеграционного сотрудничества». В этой связи необходимо поговорить о том, существуют ли на данном этапе условия для формирования единой валюты, какие перспективы имеет идея о введении данной меры.

По мнению аналитиков, реализация разнообразных форм валютной интеграции в процессе сближения государств-членов ЕАЭС создает предпосылки для эффективного экономического развития. Если, допустим, проводить параллели с Европейским союзом, то, несмотря на сегодняшнюю трудную для союза ситуацию, как экономическое и валютное объединение ЕС продолжает нивелировать влияние неблагоприятных ситуаций в мировой экономике, что в очередной раз доказывает целесообразность валютной интеграции.

Для Евразийского союза приоритетными направлениями в области валютной интеграции являются: увеличение доли расчетов в национальных валютных между странами-участницами; расширение использования таких валют за рубежом; дедолларизация на валютных рынках данных стран; повышение уровня доверия к национальным валютам и др. ${ }^{3}$

Проблемы у введения единой валюты есть: недостаточный уровень экономического развития; структурные диспропорции; разные темпы развития экономики стран; пробелы и коллизии в правовом поле (по объективным причинам в силу незавершенности интеграции); текущие кризисные состояния. Из субъективных причин: никто не хочет переходить на российский рубль.

Это, впрочем, весьма обоснованно. Достойной конкуренции мировым валютам со стороны рубля пока ждать не приходится. Ни одна из стран-

\footnotetext{
${ }^{3}$ См. там же.
} 
участниц Союза не готова пожертвовать своими национальными интересами, принципами в проведении экономической политики, ведь потеря контроля над национальной денежно-кредитной политикой будет налицо. К тому же, разница между ВВП России и другими странами Союза наводит на следующую реалию: единым эмиссионным центром будет руководить Россия. ${ }^{4}$

В связи с этим возникает вопрос о введении совершенно другой валюты, по типу евро в ЕС. Здесь наиболее активно выступает Казахстан, по прагматичным соображениям.

При использовании российского рубля наиболее вероятным сценарием развития событий может считаться сохранение контроля Банка России над эмиссией валюты. Новая же валюта, скорее всего, вызовет создание нового эмиссионного центра. Поддерживая этот вариант, другие страны-участницы хотят получить равные права с Россией на управление межгосударственным финансовым органом.

Введение единой валюты можно рассматривать только как шаг в долгосрочной перспективе. И всё-таки, подобный шаг открывает новые возможности: страны с высокой инфляции (особенно Беларусь) получат значительный положительный эффект, темпы инфляции вообще будут снижены; валюта повысит инвестиционную привлекательность Союза; будут сняты барьеры на пути движения товаров и капиталов между странами; дедолларизация как конечная цель откроет соответствующие перспективы и др. ${ }^{5}$

\footnotetext{
${ }^{4}$ См. об этом: Ломакин В. К. Мировая экономика. М., ЮНИТИ, 2012.

5 Макаровский М. Д. Стратегическая цель интеграционного сотрудничества ЕврАзЭС в валютной сфере // Международная экономика, 2014, № 5, С. 38 - 42.
} 